\title{
Immediate effect of foot reflexology in patients with diabetic neuropathy: Randomized Clinical Trial
}

\author{
Efeito imediato da reflexologia podal em pacientes com \\ neuropatia diabética: Ensaio clínico randomizado
}

\section{Efecto inmediato de la reflexología podal en pacientes con neuropatía diabética: Ensayo clínico aleatorizado}

\author{
Larissa de Fátima Megda ${ }^{1}$, Andréia Maria Silva Vilela Terra ${ }^{2}$, Jéssica \\ Beatriz de Matos $^{1}$, Larissa de Melo Taveira ${ }^{1}$, Beatriz Bertolaccini \\ Martínez ${ }^{3}$, Rita de Cássia Pereira ${ }^{4}$, Sidney Benedito Silva ${ }^{5}$, Luciana \\ Maria dos Reis ${ }^{2}$, Carolina Kosour ${ }^{2}$, Adriana Teresa Silva Santos ${ }^{2}$

\footnotetext{
1.Student of the Physiotherapy course of the Federal University of Alfenas (UNIFAL). Alfenas-MG, Brazil. 2.Physiotherapist, professor of Physical Therapy at the UNIFAL. Alfenas-MG, Brazil.

3.Nephrologist, professor of Medicine at the University of Vale of Sapucaí (UNIVAS). Pouso Alegre-MG, Brazil.

4.Nurse, lecturer in the nursing course at the UNIVAS. Pouso Alegre-MG, Brazil.

5.Physiotherapist, lecturer in the physiotherapy course at the UNIVAS, Pouso Alegre-MG, Brazil.
}

\section{Resumo}

Introdução. A neuropatia diabética (ND) é uma das complicações crônicas mais frequentes do diabetes mellitus tipo 2 (DM2). Uma técnica capaz de influenciar o sistema nervoso central e periférico é a reflexologia podal (RP). Portanto, o objetivo deste estudo foi analisar o efeito imediato da RP em pacientes com ND tipo 2. Método. Trata-se de um ensaio clínico randomizado e controlado, com 12 participantes selecionados de uma lista de diabéticos de Unidades Básicas de Saúde do município de Alfenas-MG. A amostra foi composta por dois grupos: Grupo Controle $(n=5)$ e Grupo Intervenção $(n=7)$. Os instrumentos utilizados foram: eletromiografia de superfície para análise dos músculos gastrocnêmios lateral e medial, baropodometria para avaliação do equilíbrio a partir das variáveis pressão média e divisão da massa e cardiofrequencímetro para análise da relação entre sistema nervoso simpático e parassimpático e estresse cardiovascular. Para análise estatística foi utilizado o teste de Shapiro-Wilk e posteriormente o teste $t$ independente e Mann Whitney para comparação intergrupos. Resultados. Houve diferença apenas na EMG do músculo gastrocnêmio lateral direito $(p=0,04)$. Conclusão. Concluiu-se que a RP foi capaz de gerar resposta na atividade elétrica muscular, além de influenciar no equilíbrio de pacientes com ND2.

Unitermos. Diabetes Mellitus; Neuropatias diabéticas; Reflexologia; Reabilitação; Terapias Complementares

\begin{abstract}
Introduction. Diabetic neuropathy (DN) is one of the most frequent chronic complications of type 2 diabetes mellitus (DM2). One technique capable of influencing the central and peripheral nervous system is foot reflexology (FR). Therefore, the objective of this study was to analyze the immediate effect of FR in DN type 2 patients. Method. This was a randomized controlled clinical trial, with 12 participants selected from a list of diabetic patients from the Basic Health Units of the city of Alfenas-MG. The sample consisted of two groups: Control Group $(n=5)$ and Intervention Group $(n=7)$. The instruments used were: surface electromyography for analysis of the lateral and medial gastrocnemius muscles, baropodometry to evaluate the balance from the variables of mean pressure and mass division, and the cardiofrequency meter to analyze the relationship between the sympathetic and parasympathetic nervous system and cardiovascular stress. Statistical analysis was used the Shapiro-Wilk test and later the independent t test and Mann Whitney for intergroup comparison. Results. There was only a difference in the EMG of the right lateral gastrocnemius muscle $(p=0.04)$. Conclusion. It was
\end{abstract}


concluded that FR was able to generate response in muscle electrical activity, besides influencing the balance of DN2 patients.

Keywords. Diabetes Mellitus; Diabetic Neuropathies; Reflexology; Rehabilitation; Complementary Therapies

\begin{abstract}
Resumen
Introducción. La neuropatía diabética (ND) es una de las complicaciones crónicas más frecuentes de la diabetes mellitus tipo 2 (DM2). Una técnica capaz de influir en el sistema nervioso central y periférico es la reflexología podal (RP). Por tanto, el objetivo de este estudio fue analizar el efecto inmediato de la RP en pacientes con ND tipo 2. Método. Se trata de un ensayo clínico controlado aleatorizado, con 12 participantes seleccionados de una lista de pacientes diabéticos de las Unidades Básicas de Salud de la ciudad de Alfenas-MG. La muestra estuvo compuesta por dos grupos: Grupo de control $(n=5)$ y Grupo de intervención $(n=7)$. Los instrumentos utilizados fueron: electromiografía de superficie para análisis de los músculos gastrocnemios lateral y medial, baropodometría para evaluar el equilibrio a partir de las variables de presión media y división de masa, y el medidor de cardiofrecuencia para analizar la relación entre el sistema nervioso simpático y parasimpático y el estrés cardiovascular. . Para el análisis estadístico se utilizó la prueba de Shapiro-Wilk y posteriormente la prueba $\mathrm{t}$ independiente y Mann Whitney para la comparación intergrupal. Resultados. Solo hubo una diferencia en la EMG del músculo gastrocnemio lateral derecho $(p=0,04)$. Conclusión. Se concluyó que la RP fue capaz de generar respuesta en la actividad eléctrica muscular, además de influir en el equilibrio de los pacientes con ND2.
\end{abstract}

Palabras clave. Diabetes mellitus; Neuropatías diabéticas; Reflexología; Rehabilitación; Terapias complementarias

Research developed at Federal University of Alfenas (UNIFAL). Alfenas-MG, Brazil.

Corresponding address: Adriana TS Santos. UNIFAL, Institute of Motor Science. Av Jovino Fernandes Sales 260, Santa Clara, CEP 37133-840, Alfenas-MG, Brazil. Phone: +55 (35) 37011921. E-mail: adrianat.silva@yahoo.com.br

\title{
INTRODUCTION
}

Diabetes Mellitus (DM) is a chronic disease characterized by a multifactorial metabolic disorder that affects a large part of the population ${ }^{1}$. According to estimates by the International Diabetes Federation (IDF), in 2017 about 425 million people worldwide were diagnosed with DM and in Brazil there are more than 12 million cases ${ }^{2}$. It is worth mentioning that approximately $90 \%$ of individuals present type 2 diabetes mellitus (DM2) ${ }^{3}$ due to dysfunction 
in the secretion and/or mechanism of action of insulin in the $\operatorname{organism}^{1,4}$.

Diabetic neuropathy (DN) is one of the most frequent chronic complications of DM2, with distal symmetric polyneuropathy being the most common clinical form involving multiple pathophysiological mechanisms such as neurodegenerative, vascular, metabolic, and inflammatory changes 5 . It is estimated that about $50 \%$ to $75 \%$ of DN cases remain underdiagnosed and asymptomatic, increasing the risk of various complications, including amputation of the lower limbs ${ }^{6}$. This happens because DN presents a degenerative character leaving the feet vulnerable to the appearance of lesions, which directly affects the quality of life of the individual?.

Different therapeutic approaches aim to soften the consequences related to DN, among them the techniques of Traditional Chinese Medicine (TCM), currently being used by the National Health Care System, since the World Health Organization (WHO) is stimulating the use of Integrative and Complementary Practices (ICP) ${ }^{8}$. As an example of ICP stands out the application of acupuncture in the treatment of DN. A study conducted in 2018 found that after performing systemic laser acupuncture and with needles at points located in the feet, improved nerve conduction and control of clinical and subjective symptoms of ND ${ }^{9}$. There are also studies with the use of foot reflexology (FR) in the treatment of $\mathrm{DM}^{10-12}$. 
FR is a popular and non-invasive TCM technique based on reflex zones that has as its principle the general balance of the body and adequate energy circulation of the organs and viscera ${ }^{13}$. This technique is based on the application of pressure on the tissular surface of specific points of the feet, which when stimulated, trigger functional responses in the organism ${ }^{14}$. Currently FP is well known for its physiological and neurophysiological effects such as activation of blood and lymphatic circulation, decreased pain, and stress; reduction of fatigue, improvement of balance and functionality and restoration of quality of life ${ }^{15-18}$. The literature does not describe the effect of this technique on the autonomic nervous system (ANS), plantar area and electrical activity of the lateral gastrocnemius (GL) and medial (GM) muscle affected by DN. Therefore, the first hypothesis is that the ANS be influenced after 30 minutes of FP. The second hypothesis is that FR has an effect on the plantar area due to the possible change in balance. Finally, the last hypothesis is that after the immediate stimulation of reflex zones of the feet a modification of the electromyographic signal of the GL and GM muscles occurs.

The present study aimed to analyze the immediate effect of FR in patients with type 2 diabetic neuropathy. 


\section{METHOD}

\section{Study design}

It is a randomized controlled clinical trial that was approved by the Research Ethics Committee of the Foundation of Higher Education do Sapucaí (\#659.819). All participants were informed in accordance with the objectives and procedures and signed an Informed Consent Term.

\section{Sample}

Participants were recruited from February to August 2018. 116 individuals with DM were contacted from a list of Basic Health Units (BHU) in the city of Alfenas-MG. Of these, 45 participants were selected who answered the call, and 17 were excluded because they did not meet the inclusion criteria: age between 55 and 75 years, 10 years or more onset of 2DM, Body Mass Index (BMI) less than $29,9 \mathrm{~kg} / \mathrm{m} 2$ and present a score above three by the scale of neuropathic impairment and symptoms ${ }^{19}$. Thirty-eight subjects were then left with two groups: Control Group ( $C G, n=14$ ) and Intervention Group (IG, $n=14$ ). There was a sample loss of both groups due to non-attendance on the day of care. Thus, five subjects remained for the CG and seven for the IG. Exclusion criteria were superior motor neuron injury, constant use of muscle relaxant, need for gait aid, and orthopedic, circulatory and / or dermatological problems of the lower extremities (Figure 1). 


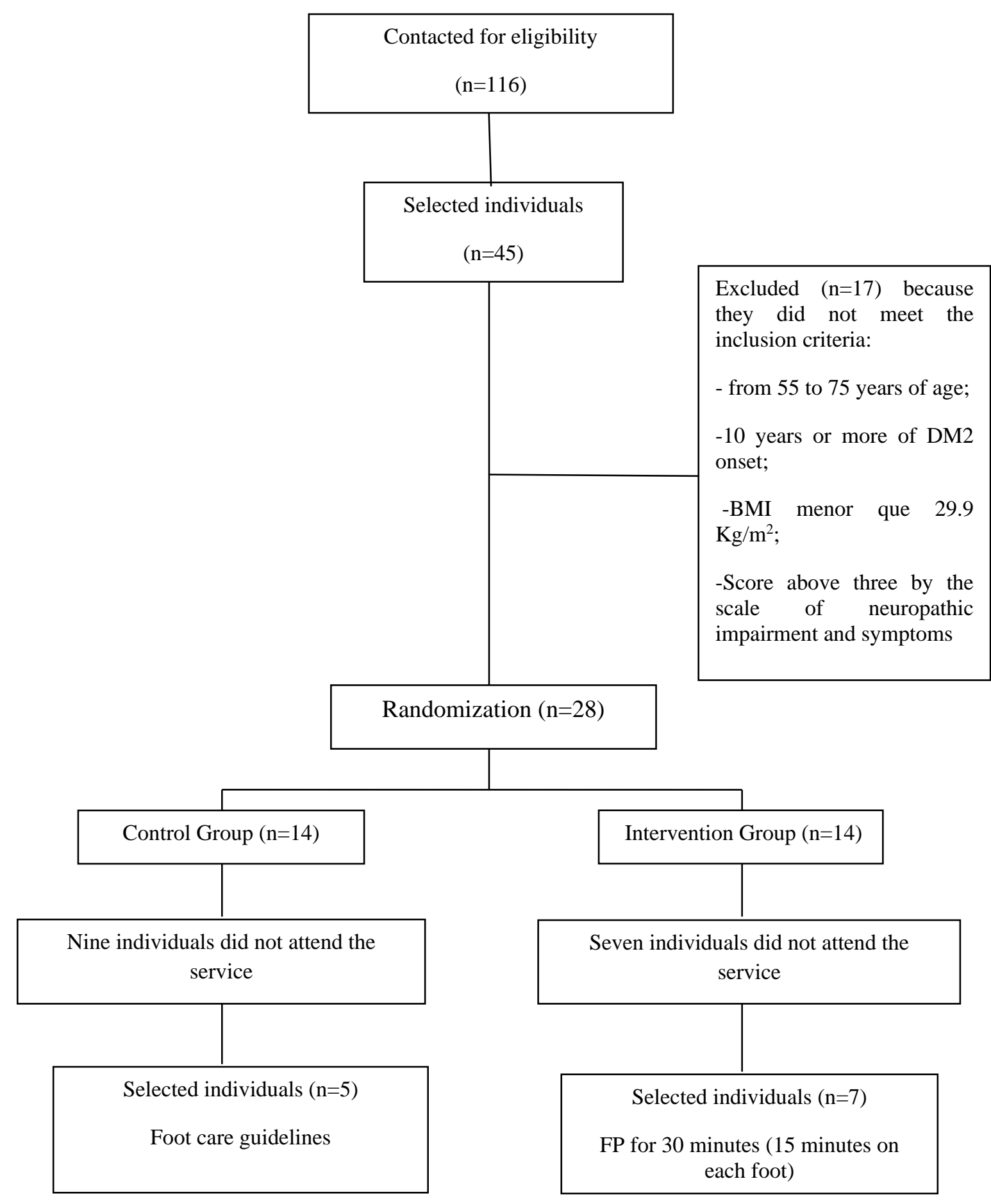

Figure 1. Sample selection flowchart according to CONSORT standards.

The sample calculation was performed using the $G$ Power 3.1 program, with an alpha of 0.05 and power of 0.9 . The EMG RMS variable was used to analyze the calculation, with 46 individuals assigned to each group. 


\section{Procedure}

Evaluation and revaluation instruments

Initially the individuals were evaluated by an evaluation form standardized by the researchers with the following clinical and anthropometric data: age, gender, weight, height, BMI and time of diagnosis of 2DM.

1. Heart rate variability (HRV)

The HRV evaluation was performed using the Polar $\AA$ V800 HR GPS heart rate monitor that allows the calculation of HRV using the Poincaré plot, in which each RR interval is plotted on Cartesian graph as a function of the previous RR interval, by adjusting the points in an ellipse, in which longitudinal axis is the standard deviation "a" (SD2), which expresses the tendency of the set of RR intervals analyzed in the long term; and the transverse axis represents the standard deviation "b" (SD1), which expresses the instantaneous variability of the R-R intervals without trend influence ${ }^{20}$.

In order to collect the HRV data, the subjects were positioned in a sitting position for five minutes. The cardiofrequency meter was positioned in the chest region at the level of the armpits. The HRV recording at rest was performed for five minutes, since the frequency domain was used to analyze the relationship between sympathetic and parasympathetic nervous system (LF/HF), which reflects the absolute and relative changes system and cardiovascular stress $^{21}$ (Figure 2). 


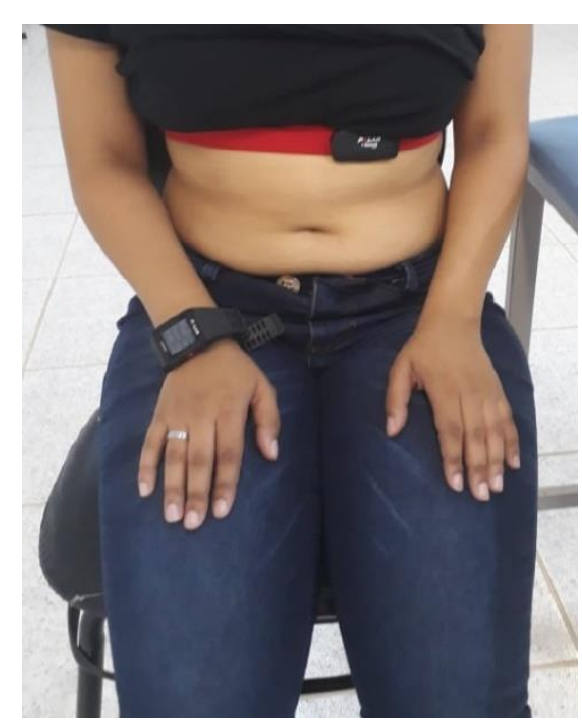

Figure 2. Positioning of the cardiofrequency meter for HRV recording.

\section{Surface electromyography (EMG)}

The EMG signal was obtained using the four channel input model (EMG System do Brasil Ltda $®$ ), 16-bit analogue resolution (EMG System do Brasil Ltda $($ ) with sampling frequency of $2000 \mathrm{~Hz}$ for digital conversion plate, consisting of a filter band pass from 20 to $500 \mathrm{~Hz}$, four active monolith electrodes with 20 times gain preamp, common rejection mode rate $>100 \mathrm{~dB}$ and software for sampling and analysis of signals with $2000 \mathrm{~Hz}$ sampling frequency per channel. Windows platform, common rejection mode is $100 \mathrm{~dB}$, gain of preamplifiers (cables) of 20 times and amplifier of total gain of 1000 times. We used monopolar electrodes positioned in the $\mathrm{GL}$ and $\mathrm{GM}$ muscles where the electromyographic signal was collected bilaterally simultaneously.

The skin was cleaned with $70 \%$ alcohol and tricotomy to reduce the impedance and consequently to obtain a better 
EMG signal, and then the electrodes were placed in the GL and GM according to the electromyographic procedures ${ }^{22}$

The EMG collection of the GL and GM muscles was performed in the orthostatic posture in the maximal voluntary isometric contraction (MVIC) and isotonic contraction (IC) for five seconds with three repetitions, respecting a one minute interval between each repetition being evaluated and re-evaluated by the same examiner (Figure 3).

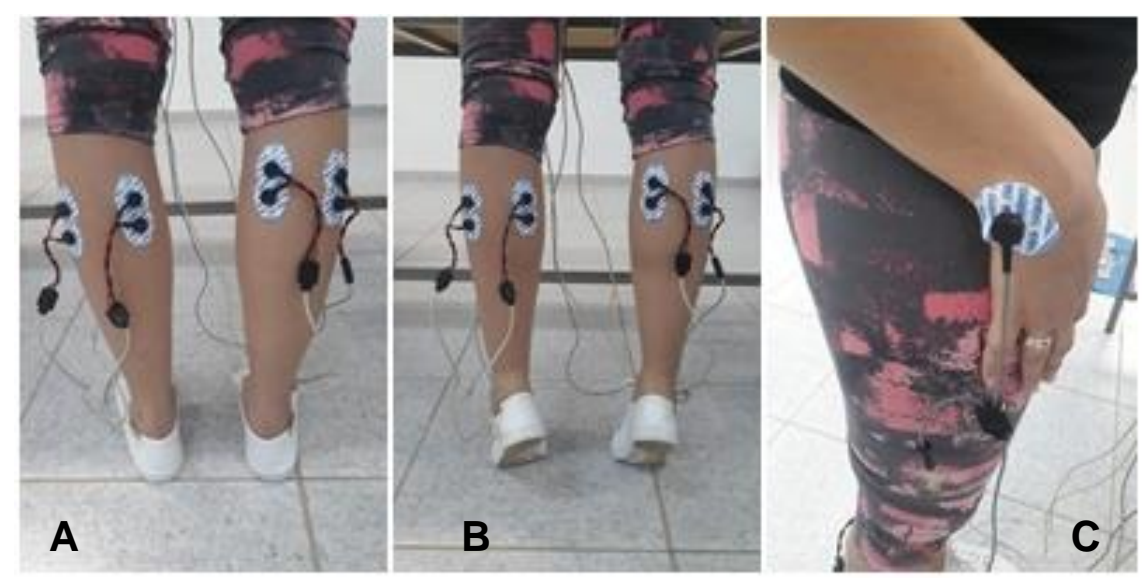

Figure 3. Positioning of the electrodes for electrographical data collection.(A) Shows the position of the active electrode in the resting gastrocnemius muscle (B) Shows the MIVC and CI muscle of the GL and GM muscle (C) Shows the positioning of the reference electrode on the styloid process of ulna $D$.

The EMG signal processing was obtained as follows: the data were processed by the EMG System do Brasil Ltda ${ }^{\circledR}$ program, in which it performed "windowing" of three seconds, excluding the first and last second, the Root Mean square (RMS) of each collection was recorded. The average of the three collections was calculated. Among the three collections selected the highest value. The average of the 
three values was divided by the highest value of the collection and multiplied by $100 \%$ for the RMS variables.

\section{Baropodometry}

For the data collection of the baropodometry used the apparatus of the brand Arkipelago $($. The subjects were placed barefoot in the orthostatic posture with bipodal support maintaining $10 \mathrm{~cm}$ between the feet and the base of the platform. The platform was positioned one meter from the wall and individuals were instructed to keep their eyes fixed, taking as a reference a fixed point on the wall at eye level, relaxed arms along the body without occlusal contact. First, it was performed with eyes open and without handset, therefore with eyes closed and with phone use for 30 seconds ${ }^{23}$.

The variables mean pressure (MP) and mass division (MD) were collected by the instrument for analysis (Figure 4).

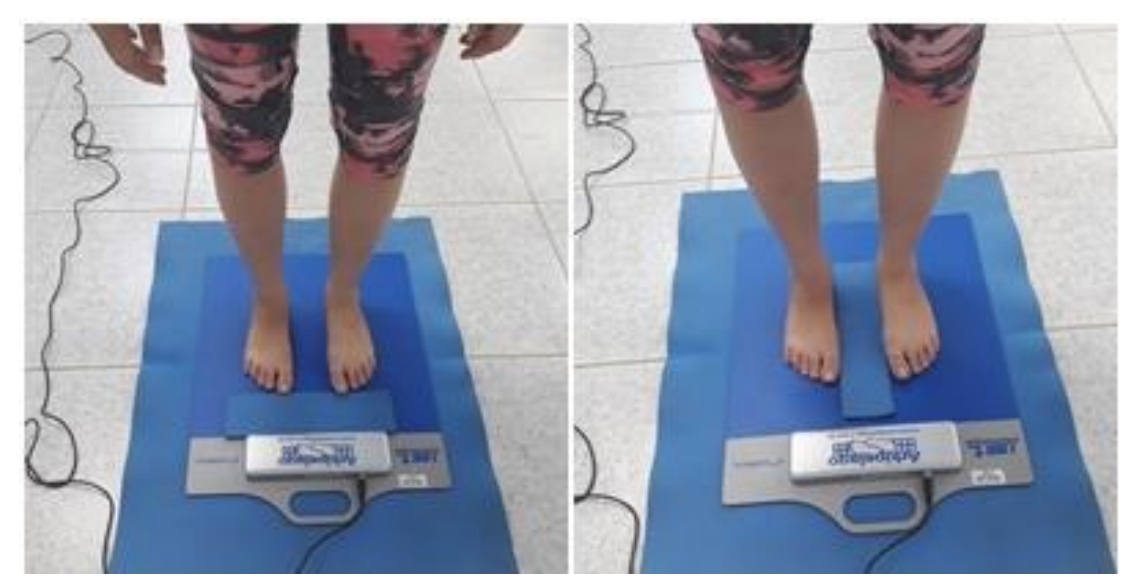

Figure 4. Positioning of the individual on the baropodometry platform for data collection. 
Foot Reflexology

Initially, the individual was placed in the supine position with the support of a cushion below the knees, keeping them semi-stiff. Subsequently, 70\% alcohol asepsis was performed. Then the trained trainer was applied to FR by performing deep, non-shallow pressure ${ }^{24}$ on reflex zones throughout the foot for 30 minutes (15 minutes on each foot) following the step-by-step procedure shown in the figure below. For the application of FR, mineral oil (JOHNSON'S $\mathbb{\text { }}$ baby) was used and the technique was performed in a quiet and comfortable environment with minimal external interference (Figure 5).

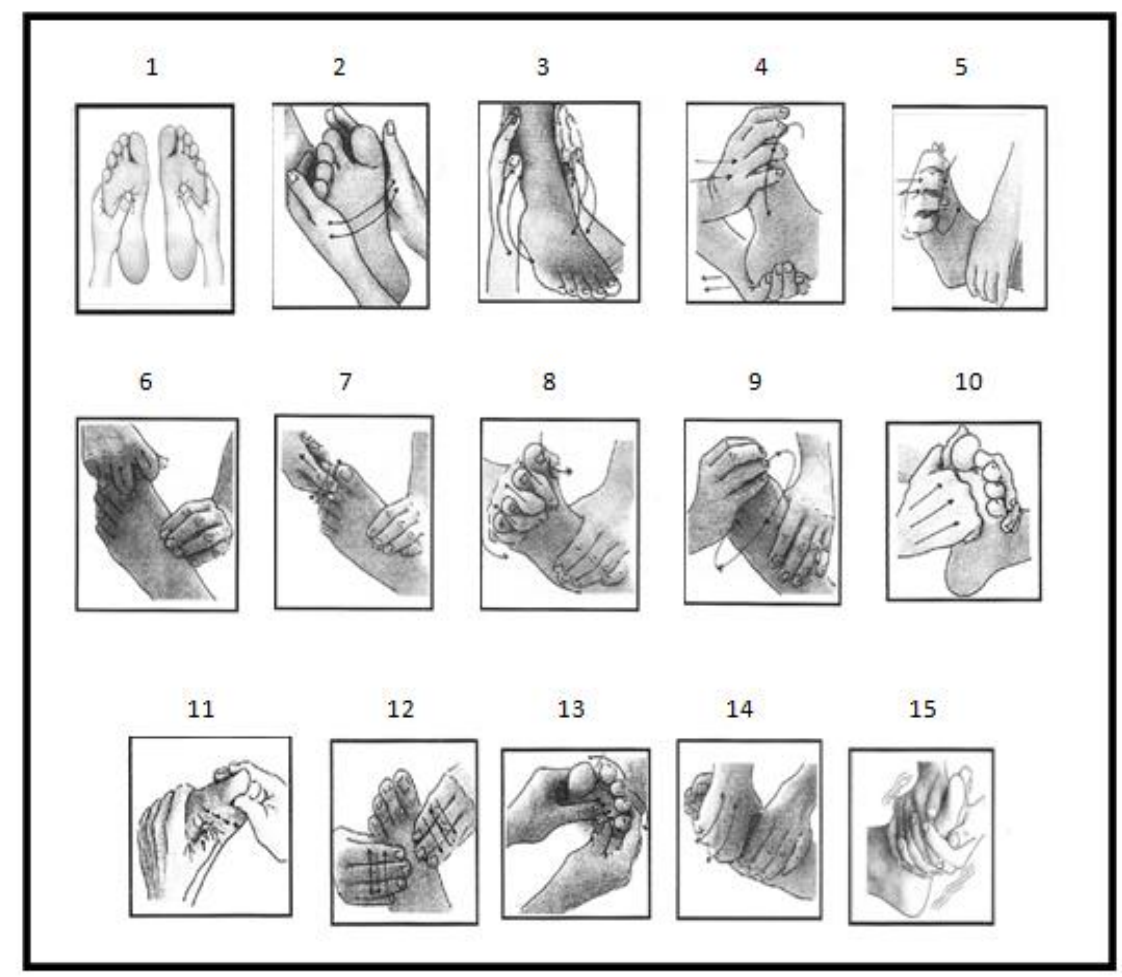

Figure 5. Demonstrates the step-by-step of foot reflexology. 1- Breathing as Harmonization in the Solar Plexus; 2-Releasing the Scapular Waist; 3 - Releasing the Pelvic Girdle; 4- Stretching the Tendon; 5 - Releasing the Pelvic Girdle; 6 Tractioning the Musculature of the Neck; 7- Stretching the Musculature of the Neck; 8 - Releasing the tension of the head and neck; 9- Relaxing the Head; 10- Relaxing the Lung; 11-Relaxing the Diaphragm; 12-Releasing the Ribs; 13-Relaxing the Ribs; 14- Releasing the Vertebrae of the Spine; 15- Embrace Maneuver. 
The entire procedure was performed on the same day, evaluation, and reassessment. First, the data of the HRV, EMG, baropodometry, FP application and reevaluation were collected following the same sequence of the evaluation (Figure 6).

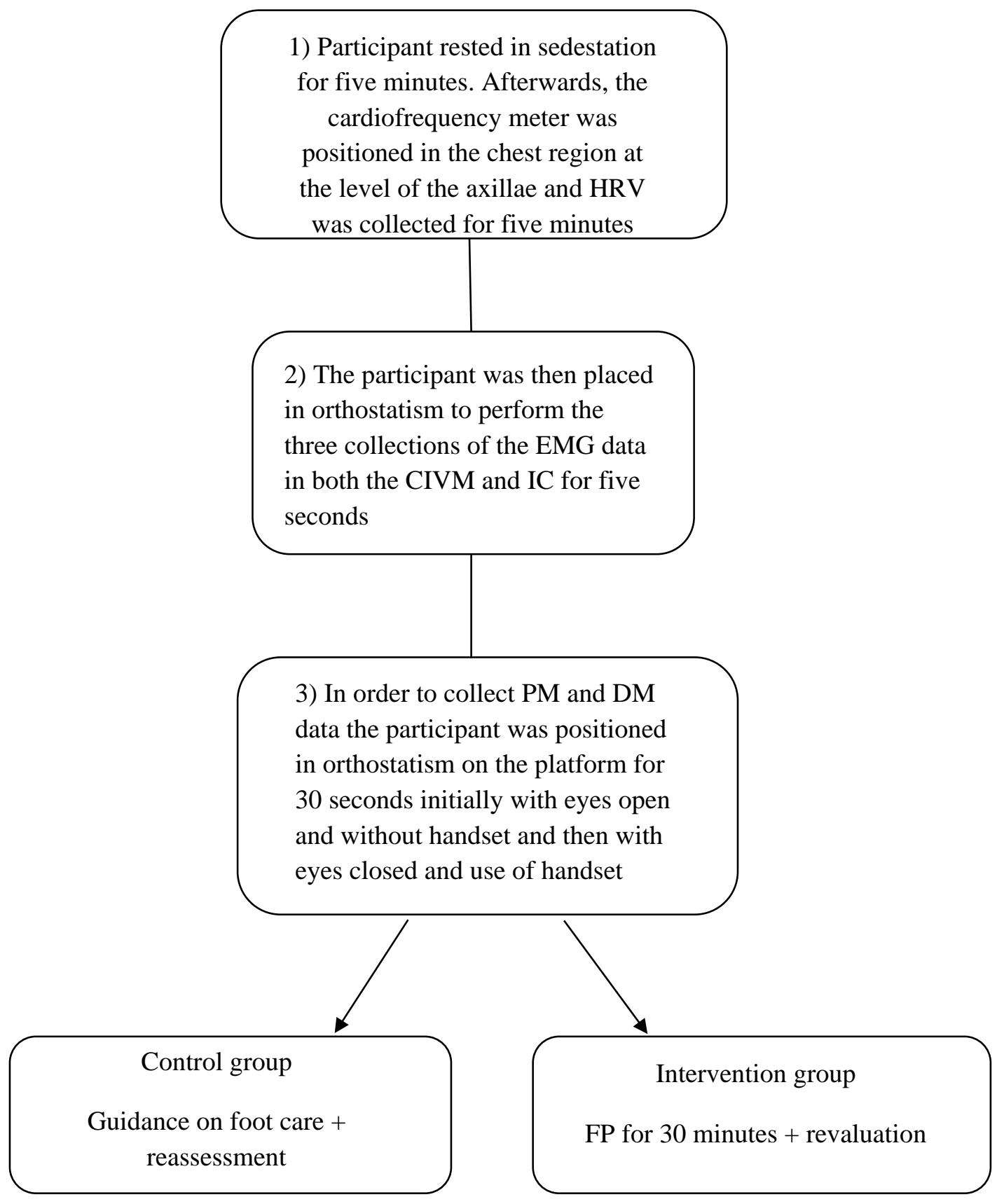

Figure 6. Schematization of the experimental protocol. 


\section{Statistical analysis}

Descriptive statistics were used to characterize the sample in relation to clinical and demographic data. The Shapiro-Wilk test was used to determine the normality of the data. The independent t-test was applied for variables: mass, height, age, body mass index (BMI), baropodometry and EMG; and Mann Whitney test for the HRV variable.

\section{RESULTS}

The demographic data of the CG and GI regarding the variables age, height, mass, BMI, and gender were described in Table 1 . The groups did not differ in relation to height, mass, and BMI, but they differed in relation to age.

Table 1. Demographic characteristics of the sample.

\begin{tabular}{lccc}
\hline & IG $(n=7)$ & CG $(n=5)$ & $\begin{array}{c}P \text { Value } \\
\text { Intergroup }\end{array}$ \\
\hline Age & $66.00 \pm 5.00$ & $66.20 \pm 2.48$ & $\mathbf{0 . 0 3}$ \\
\hline Weight & $66.95 \pm 9.43$ & $65.45 \pm 11.49$ & 0.47 \\
\hline Height & $1.49 \pm 0.66$ & $1.49 \pm 0.08$ & 0.32 \\
\hline BMI & $29.81 \pm 2.58$ & $29.20 \pm 4.58$ & 0.55 \\
\hline
\end{tabular}

IG: intervention group; CG: control group; BMI: Body mass index. 
Table 2 describes the HR of the CG and IG in relation to stress variables and the relationship between sympathetic and parasympathetic nervous system (LF/HF). It was observed that there was no difference.

Table 2. Comparison between IG and CG of HRV for stress and LH/HF ratio variables.

\begin{tabular}{|c|c|c|c|c|c|c|}
\hline & $\begin{array}{l}\text { Before } \\
\text { (IG) } \\
\text { CI }\end{array}$ & $\begin{array}{l}\text { After } \\
\text { (IG) } \\
\text { CI }\end{array}$ & $\begin{array}{c}\text { Before } \\
\text { (CG) } \\
\text { CI }\end{array}$ & $\begin{array}{l}\text { After } \\
\text { (CG) } \\
\text { CI }\end{array}$ & $\begin{array}{c}P \text { Value } \\
\text { Intergroup } \\
\text { Before }\end{array}$ & $\begin{array}{c}P \text { Value } \\
\text { Intergroup } \\
\text { After }\end{array}$ \\
\hline \multirow{2}{*}{ STRESS } & $6.16 \pm 5.25$ & $10.41 \pm 8.41$ & $8.64 \pm 9.39$ & $8.20 \pm 7.76$ & \multirow{2}{*}{0.51} & \multirow{2}{*}{0.37} \\
\hline & 1.30 to 11.01 & 2.63 to 18.19 & -3.02 to 20.30 & -1.44 to 17.84 & & \\
\hline \multirow{2}{*}{$L F / H F$} & $1.16 \pm 1.73$ & $1.25 \pm 1.12$ & $2.56 \pm 4.72$ & $1.90 \pm 2.87$ & 0.93 & 0.87 \\
\hline & -044 to 276 & 022 to 220 & -330 to 843 & 5.45 & & \\
\hline
\end{tabular}

IG: intervention group; CG: control group; CI: Confidence interval; LF/HF: relationship between sympathetic and parasympathetic nervous system.

Tables 3 and 4 describe the GC and GI variables of the EMG being RMS of the MVIC and, CI respectively. It was noticed that there was a reduction in GL right side muscle in IC $(p<0.05)$. The $G L$ left side muscle and GM right side muscle of IC and GM left side muscle of the MVIC were influenced by FP but were not significant.

Tables 5 and 6 describe the variables mean pressure (MP) and mass division (MD) of foot without use of earphone and open eyes and with use of earphone and closed eyes for the CG and IG. With use of earphone mass division on the right side of the foot (DMFD) was influenced by FP but was not significant. 
Table 3. comparison between IG and CG of the EMG for RMS in the MIVC variable.

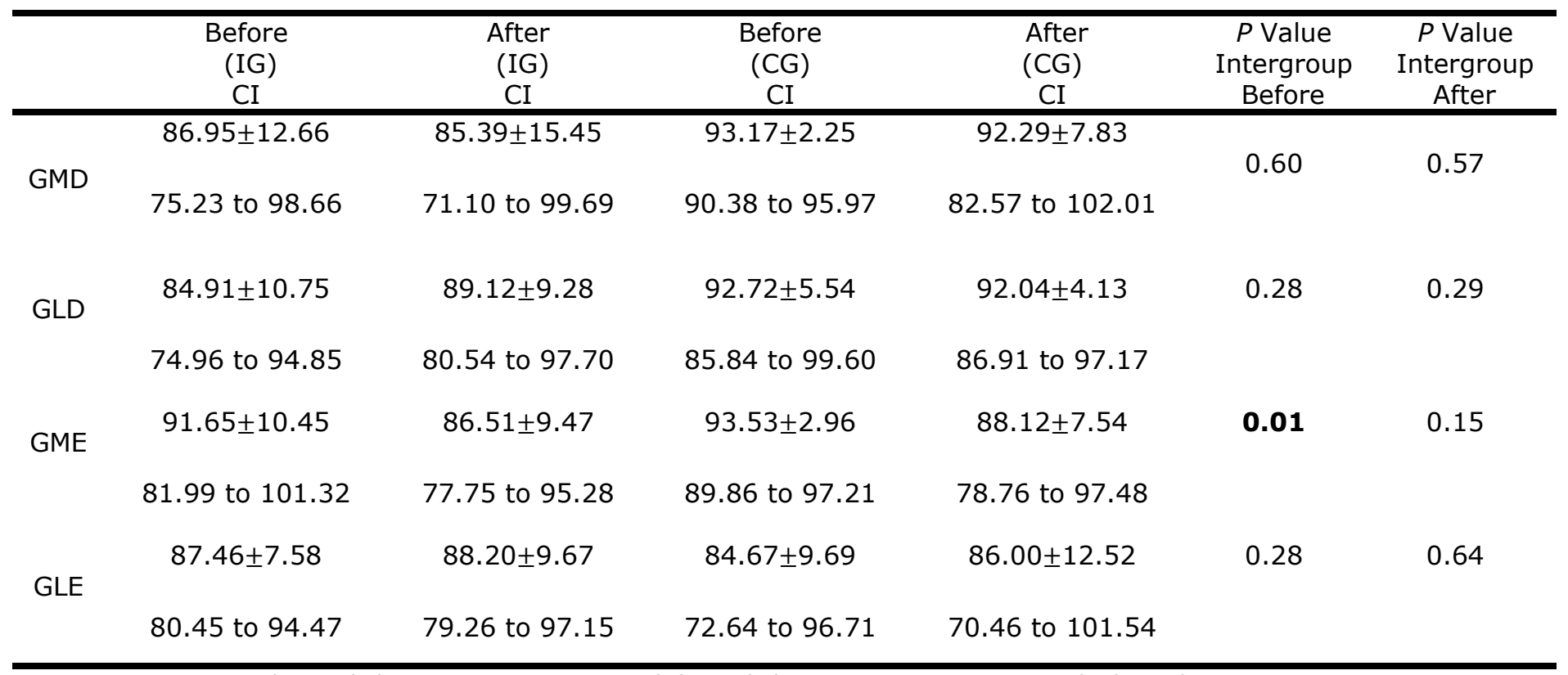

GMD: right medial gastrocnemius; GME: left medial gastrocnemius; GLD: right lateral gastrocnemius;

GLE: left lateral gastrocnemius; IG: intervention group; CG: control group; CI: Confidence interval.

Table 4. comparison between IG and CG of the EMG for RMS in the IC variable.

\begin{tabular}{|c|c|c|c|c|c|c|}
\hline & $\begin{array}{c}\text { Before } \\
\text { (IG) } \\
\text { CI }\end{array}$ & $\begin{array}{c}\text { After } \\
\text { (IG) } \\
\text { CI }\end{array}$ & $\begin{array}{c}\text { Before } \\
\text { (CG) } \\
\text { CI }\end{array}$ & $\begin{array}{c}\text { After } \\
\text { (CG) } \\
\text { CI }\end{array}$ & $\begin{array}{c}P \text { Value } \\
\text { Intergroup } \\
\text { Before }\end{array}$ & $\begin{array}{c}P \text { Value } \\
\text { Intergroup } \\
\text { After }\end{array}$ \\
\hline \multirow[b]{2}{*}{ GMD } & $90.02 \pm 8.11$ & $92.35 \pm 4.70$ & $94.72 \pm 1.90$ & $94.94 \pm 4.97$ & \multirow[b]{2}{*}{0.07} & \multirow[b]{2}{*}{0.92} \\
\hline & 82.52 to 97.52 & 88.01 to 96.70 & 92.36 to 97.08 & 87.88 to 100.22 & & \\
\hline \multirow{2}{*}{ GLD } & $91.92 \pm 5.82$ & $89.39 \pm 10.04$ & $91.44 \pm 5.10$ & $95.13 \pm 2.57$ & \multirow[t]{2}{*}{0.57} & \multirow[t]{2}{*}{0.04} \\
\hline & 86.54 to 97.31 & 80.10 to 98.68 & 85.12 to 97.77 & 91.93 to 98.32 & & \\
\hline \multirow[t]{2}{*}{ GME } & $88.58 \pm 6.82$ & $89.35 \pm 7.30$ & $92.89 \pm 2.50$ & $95.94 \pm 3.62$ & \multirow[t]{2}{*}{0.02} & \multirow[t]{2}{*}{0.05} \\
\hline & 82.27 to 94.89 & 82.60 to 92.11 & 89.78 to 95.99 & 91.44 to 100.43 & & \\
\hline \multirow[t]{2}{*}{ GLE } & $88.65 \pm 7.88$ & $87.72 \pm 8.38$ & $93.34 \pm 2.88$ & $89.53 \pm 8.60$ & \multirow[t]{2}{*}{0.06} & \multirow[t]{2}{*}{0.87} \\
\hline & 81.36 to 95.95 & 79.96 to 95.47 & 89.76 to 96.91 & 78.85 to 100.21 & & \\
\hline
\end{tabular}

GMD: right medial gastrocnemius; GME: left medial gastrocnemius; GLD: right lateral gastrocnemius; GLE: left lateral gastrocnemius; IG: intervention group; CG: control group; CI: Confidence interval. 
Table 5. Comparison between IG and CG of baropodometry without a phone and open eyes.

\begin{tabular}{|c|c|c|c|c|c|c|}
\hline & $\begin{array}{l}\text { Before } \\
\text { (IG) } \\
\text { CI }\end{array}$ & $\begin{array}{l}\text { After } \\
\text { (IG) } \\
\text { CI }\end{array}$ & $\begin{array}{l}\text { Before } \\
\text { (CG) } \\
\text { CI }\end{array}$ & $\begin{array}{l}\text { After } \\
\text { (CG) } \\
\text { CI }\end{array}$ & $\begin{array}{l}P \text { Value } \\
\text { Intergroup } \\
\text { Before }\end{array}$ & $\begin{array}{c}P \text { Value } \\
\text { Intergroup } \\
\text { After }\end{array}$ \\
\hline \multirow[b]{2}{*}{ MPER } & $34.45 \pm 8.50$ & $33.54 \pm 8.01$ & $29.35 \pm 3.56$ & $28.70 \pm 3.57$ & \multirow[b]{2}{*}{0.33} & \multirow[b]{2}{*}{0.38} \\
\hline & 26.55 to 42.31 & 26.13 to 40.95 & 24.92 to 33.77 & 24.26 to 33.14 & & \\
\hline \multirow{2}{*}{ MPEL } & $31.91 \pm 10.27$ & $35.87 \pm 9.65$ & $30.42 \pm 6.26$ & $30.49 \pm 6.30$ & \multirow{2}{*}{0.57} & \multirow{2}{*}{0.36} \\
\hline & 22.42 to 38.19 & 26.95 to 44.79 & 22.64 to 38.19 & 22.67 to 38.31 & & \\
\hline \multirow{2}{*}{ MDER } & $0.36 \pm 0.095$ & $0.38 \pm 0.085$ & $0.43 \pm 0.052$ & $0.45 \pm 0.048$ & \multirow{2}{*}{0.26} & \multirow{2}{*}{0.34} \\
\hline & 0.28 to 0.45 & 0.30 to 0.46 & 0.36 to 0.49 & 0.40 to 0.51 & & \\
\hline \multirow[b]{2}{*}{ MMEL } & $0.43 \pm 0.090$ & $0.40 \pm 0.073$ & $0.47 \pm 0.16$ & $0.47 \pm 0.14$ & \multirow[b]{2}{*}{0.24} & \multirow[b]{2}{*}{0.33} \\
\hline & 0.35 to 0.51 & 0.34 to 0.47 & 0.27 to 0.67 & 0.29 to 0.65 & & \\
\hline
\end{tabular}

MPER: Mean pressure without right earphone; MPEL: Mean pressure without left earphone; MDER: Mass division without right earphone; MMEL: Mass division without left earphone; IG: intervention group; CG: control group; CI: Confidence interval.

Table 6. Comparison between IG and CG of baropodometry with a phone and closed eyer.

\begin{tabular}{|c|c|c|c|c|c|c|}
\hline & $\begin{array}{l}\text { Before } \\
\text { (IG) } \\
\text { CI }\end{array}$ & $\begin{array}{c}\text { After } \\
\text { (IG) } \\
\text { CI }\end{array}$ & $\begin{array}{l}\text { Before } \\
\text { (CG) } \\
\text { CI }\end{array}$ & $\begin{array}{l}\text { After } \\
\text { (CG) } \\
\text { CI }\end{array}$ & $\begin{array}{l}P \text { Value } \\
\text { Intergroup } \\
\text { Before }\end{array}$ & $\begin{array}{c}P \text { Value } \\
\text { Intergroup } \\
\text { After }\end{array}$ \\
\hline \multirow[b]{2}{*}{ MPER } & $34.54 \pm 9.82$ & $34.91 \pm 9.39$ & $29.00 \pm 3.23$ & $29.18 \pm 4.39$ & \multirow[b]{2}{*}{0.33} & \multirow[b]{2}{*}{0.38} \\
\hline & 25.46 to 43.63 & 26.23 to 43.60 & 24.99 to 33.00 & 23.72 to 34.63 & & \\
\hline \multirow[t]{2}{*}{ MPEL } & $32.10 \pm 9.19$ & $33.84 \pm 8.28$ & $30.94 \pm 5.89$ & $30.07 \pm 5.53$ & \multirow[t]{2}{*}{0.55} & \multirow[t]{2}{*}{0.37} \\
\hline & 23.60 to 40.60 & 26.19 to 41.49 & 23.63 to 38.25 & 23.19 to 36.94 & & \\
\hline \multirow[t]{2}{*}{ MDER } & $0.39 \pm 0.09$ & $0.40 \pm 0.10$ & $0.41 \pm 0.04$ & $0.45 \pm 0.04$ & \multirow[t]{2}{*}{0.04} & \multirow[t]{2}{*}{0.24} \\
\hline & 0.30 to 0.47 & 0.31 to 0.50 & 0.36 to 0.46 & 0.39 to 0.51 & & \\
\hline \multirow[t]{2}{*}{ MDEL } & $0.46 \pm 0.09$ & $0.45 \pm 0.13$ & $0.48 \pm 0.19$ & $0.47 \pm 0.16$ & \multirow[t]{2}{*}{0.89} & \multirow[t]{2}{*}{0.40} \\
\hline & 0.37 to 0.55 & 0.33 to 0.57 & 0.24 to 0.71 & 0.26 to 0.67 & & \\
\hline
\end{tabular}

MPER: Mean pressure without right earphone; MPEL: Mean pressure without left earphone; MDER: Mass division without right earphone; MMEL: Mass division without left earphone; IG: intervention group; CG: control group; CI: Confidence interval. 


\section{DISCUSSION}

The main result of the present study was that the application of FP influenced GL right side muscle EMG in IC. It can be suggested that the muscular electrical activity has decreased because of the lower absorption of glucose by the cells because they are diabetic patients. The failure of skeletal muscle tissue to capture glucose at its elevated plasma levels is a contributing factor to hyperglycemia since this tissue is insulin dependent and thus the insulin resistance present in individuals with 2DM affects the translocation of GLUT 4, a glucose transporter insulinsensitive, to the sarcolemma and $\mathrm{T}$ tubules decreasing the contraction of skeletal muscle tissue ${ }^{25}$.

Immediate stimulation of the reflex zones of the feet was able to generate modification in the EMG signal of the GL right side muscle. According to Hunter et al ${ }^{26}$ after 30 minutes of massage in the posterior and anterior leg of healthy youngsters there was a decrease in isotonic muscle activity, conferring with the data presented in this study where it obtained a lower muscular activation. An immediate reduction was observed in the excitability of the alpha motoneuron after the triceps muscle massage for four minutes, confirming that the activated receptors are specific to the muscle being massaged and this is due to the presynaptic inhibition exerted by the afferent terminals ${ }^{27}$.

The GL and GM muscle architecture of sedentary youngsters at rest showed that there was no difference between the length of muscle fibers ${ }^{28}$. However, that 
massage associated with static stretching besides helping to gain flexibility ${ }^{29}$ may also contribute to the decrease in spinal reflex excitability coming from the present study.

As a result, it is noted that the execution of FP for 30 minutes was not sufficient to influence the ANS. After 25 minutes of RP, a significant decrease in relation to the heart rate (HR) of young and asymptomatic individuals occurred due to the parasympathetic action, which is not consistent with the present study ${ }^{30}$.

Another hypothesis is that both the age and the position of analysis of the test are contributing factors for the influence of the data of the present study since healthy individuals aged 51 to 60 years obtained lower HRV in the time and frequency domain after ten minutes of analysis in the supine position, observing that the sympathetic action overlaps with the parasympathetic activity ${ }^{31}$.

Cardiovascular stress is a factor that is closely related to ANS. FR had no effect on HR and stress coming from the present study, and this may be related to both the time and the manner of application of the technique ${ }^{32}$.

Regarding the MP and MD findings, it was noted that there was no statistically significant difference. These results could be justified because of having been carried out immediately. A study conducted with individuals with DN demonstrated that ten sessions were able to generate improvement in the dynamic balance ${ }^{33}$. Contradicting the study, it is observed that eight weeks of reflex massage in the elderly was not enough to modify the balance ${ }^{34}$ since 
there are still contradictory data in the literature regarding the time of data analysis.

The main limitation of this study was in relation to sampling since it was difficult to get in touch with the diabetic individuals of the BHU in the city of Alfenas-MG. Other limitations were number of sessions, massage time, orientation of non-use of stimulants (caffeine), practice of physical activity, use of alcoholic beverages and smoking 6 hours before intervention, and analysis of glycemic levels. It is noticed that in the literature there are still few studies referring to the topic addressed suggesting clinical and randomized studies to verify the real effect with the technique.

\section{CONCLUSION}

The immediate effect of FP generated a response in muscular electrical activity, besides having an influence on the balance of patients with type 2 diabetic neuropathy.

\section{ACKNOWLEDGMENT}

The authors thanks FAPEMIG Universal demand (APQ02647-16) for the financial support.

\section{REFERENCES}

1.Prabhakar PK. Pathophysiology of secondary complications of diabetes mellitus. Asian J Pharm Clin Res 2016;9:32-6. 
https://www.researchgate.net/publication/290455800 Pathophysiolo gy of secondary complications of diabetes mellitus

2.International Diabetes Federation. Bélgica. (acessado em: 14 de setembro de 2018). Disponível em: https://www.idf.org/

3.Cândido JAB, Torres GMC, Figueiredo IDT, Morais APP, Pinto FJM, Pinto AGA, et al. FINDRISK: estratificação do risco para Diabetes Mellitus na saúde coletiva. Rev Bras Prom Saúde 2017;30:1-8. http://dx.doi.org/10.5020/18061230.2017.6118

4.Zaccardi F, Webb DR, Yates T, Davies MJ. Pathophysiology of type 1 and type 2 diabetes mellitus: a 90-year perspective. Postgrad Med J 2015;92:63-9.

http://dx.doi.org/10.1136/postgradmedj-2015-

133281

5.Pop-Busui R, Boulton AJM, Feldman EL, Bril V, Freeman R, Malik RR, et al. Diabetic Neuropathy: A Position Statement by the American Diabetes Association. Diabetes Care 2017;40:136-54. http://dx.doi.org/10.2337/dc16-2042

6. Rolim LC, Sá JR, Chacra AR, Dib SA. Heterogeneidade clínica e coexistência das neuropatias diabéticas: diferenças e semelhanças entre diabetes melito tipos 1 e 2. Arq Bras Endocr Metab 2009;53:81824. http://dx.doi.org/10.5935/1806-0013.20140055

7. Waldfogel JM, Nesbit SA, Dy SM, Sharma R, Zhang A, Wilson LM, et al. Pharmacotherapy for diabetic peripheral neuropathy pain and quality of life. Neurology 2017;88:1958-67. http://dx.doi.org/10.1212/WNL.0000000000003882

8. Ministério da Saúde. Secretaria de Atenção à Saúde. Departamento de Atenção Básica. Política nacional de práticas integrativas e complementares no SUS: atitude de ampliação de acesso. 2a. ed. Brasília: Ministério da Saúde, 2015. http://bvsms.saude.gov.br/bvs/publicacoes/politica nacional praticas integrativas complementares 2ed.pdf

9.Meyer-Hamme G, Friedemann T, Greten HJ, Plaetke R, Gerloff C Schroeder S. ACUDIN - Acupuncture and laser acupuncture for treatment of Diabetic peripheral Neuropathy: a randomized, placebocontrolled, partially double-blinded trial. BMC Neurology 2018;18:110. http://dx.doi.org/10.1186/s12883-018-1037-0

10. Hernández-Ramírez G, Barbán-Pernía J, Barbán-Hernández G, Paumier-Rodríguez I, Montero-Paumier I. Propuesta de la Reflexología como Terapéutica para la Diabetes Mellitus. Yara. 2013. MULTIMED 2016;20:1-9.

http://www.revmultimed.sld.cu/index.php/mtm/article/view/156 11.Ali-Shtayeh MS, Jamous RM, Jamous RM. Complementary and alternative medicine use amongst Palestinian diabetic patients. Complem Therap Clin Practice 2012;18:16-21. http://dx.doi.org/10.1016/j.ctcp.2011.09.001

12.Dalal K, Maran B, Pandey RM, Tripathi M. Determination of Efficacy of Reflexology in Managing Patients with Diabetic Neuropathy: A Randomized Controlled Clinical Trial. Evidence-based Complem Altern Med 2014;2014:1-11. http://dx.doi.org/10.1155/2014/843036 
13. Lourenço OT. Reflexologia Podal: sua saúde através dos pés. 5ed. São Paulo: Ground, 2012.

14.Embong NH, Soh YC, Ming LC, Wong TW. Revisiting reflexology: Concept, evidence, current practice, and practitioner training. J Tradit Complement Med 2015;5:197-206.

http://dx.doi.org/10.1016/j.jtcme.2015.08.008

15.Saatsaz S, Rezaei R, Alipour A, Beheshti Z. Massage as adjuvant therapy in the management of post-cesarean pain and anxiety: $A$ randomized clinical trial. Complement Ther Clin Pract 2016;24:92-8. http://dx.doi.org/10.1016/j.ctcp.2016.05.014

16. Metin ZG, Assistant R, Ozdemir L. The Effects of Aromatherapy Massage and Reflexology on Pain and Fatigue in Patients with Rheumatoid Arthritis: A Randomized Controlled Trial. Pain Manag Nurs 2016;17:140-9. http://dx.doi.org/10.1016/j.pmn.2016.01.004

17.Figueiredo ILGP. Efeitos da Estimulação Podal no Equilíbrio em Hemiparéticos por Acidente Vascular Cerebral. Rev Neurocienc 2014;22:12-6. http://dx.doi.org/10.4181/RNC.2014.22.890.5p

18. Özdelikara A, Tan M. The effect of reflexology on the quality of life with breast cancer patients. Complement Ther Clin Pract 2017;29:1229. http://dx.doi.org/10.1016/j.ctcp.2017.09.004

19.Moreira RO, Castro AP, Papelbaum M, Appolinário JC, Ellinger VCM, Coutinho WF, et al. Tradução para o Português e Avaliação da Confiabilidade de Uma Escala para Diagnóstico da Polineuropatia Distal Diabética. Arq Bras Endocrinol Metab 2005;49:944-50. https://doi.org/10.1590/S0004-27302005000600014

20.Lima JRP, Kiss MAPD. Limiar de variabilidade da frequência cardíaca. Rev Bras Atividade Fís Saúde 2012;4:29-38. https://doi.org/10.12820/rbafs.v.4n1p29-38

21.Lopes PFF, Oliveira MIB, André SMS, Nascimento DLA, Silva CSS, Rebouças GM, et al. Aplicabilidade Clínica da Variabilidade da Frequência Cardíaca. Rev Neurocienc 2013;21:600-3. https://doi.org/10.4181/RNC.2013.21.870.4p

22.Senian. Recommendations for sensor locations in hip or upper leg muscles. (Acessado em: 10 de outubro de 2018). Disponível em: https://www.seniam.org

23. Barcala L, Colella F, Araujo MC, Salgado ASI, Oliveira CS. Análise do equilíbrio em pacientes hemiparéticos após o treino com pograma Wii Fit. Fisioter Mov 2011;24:337-43. https://www.scielo.br/pdf/fm/v24n2/a15v24n2

24.Wang M-Y, Tsai P-S, Lee P-H, Chang W-Y, Yang C-M. The efficacy of reflexology: systematic review. J Adv Nurs 2008;62:512-20. https://doi.org/10.1111/j.1365-2648.2008.04606.x

25. Machado UF, Schaan BD, Serapfim PM. Transportadores de Glicose na Síndrome Metabólica. Arq Bras Endocrinol Metab 2006;50:177-89. https://doi.org/10.1590/S0004-27302006000200004

26. Hunter AM, Watt JM, Watt V, Galloway SDR. Effect of lower limb massage on electromyography and force production of the knee extensors. $\mathrm{Br} \mathrm{J}$ Sports Med 2006;40:114-8. https://doi.org/10.1136/bjsm.2005.019075 
27.Sullivan SJ, Williams LRT, Seaborne DE, Morelli M. Effects of Massage on Alpha Motoneuron Excitability. Phys Ther 1991;71:555-60. https://doi.org/10.1093/ptj/71.8.555

28. Martins NSF, Peixinho CC, Oliveira LF. Confiabilidade de medidas de arquitetura muscular do tríceps sural por ultrassonografia de imagem. Rev Bras Cineantropom Desempenho Hum 2012;14:212-20. https://doi.org/10.5007/1980-0037.2012v14n2p212

29.Behm DG, Peach A, Maddigan M, Aboodarda SJ, DiSanto MC, Button $\mathrm{DC}$, et al. Massage and stretching reduce spinal reflex excitability without affecting twitch contractile properties. J Electromyogr Kinesiol 2013;23:1215-21. https://doi.org/10.1016/j.jelekin.2013.05.002

30.Arbizu RLT, Raventós KE, Férnandez MTL, Días-Pardeño AS. Efecto pos-tratamiento de la reflexoterapia podal en la tensión arterial y la frecuencia cardiaca. Estudio piloto. Fisioterapia 2006;28:125-32. https://doi.org/10.1016/S0211-5638(06)74037-8

31.Paschoal MA, Volanti VM, Pires CS, Fernandes FC. Variabilidade da frequência cardíaca em diferentes faixas etárias. Rev Bras Fisioter 2006;10:413-9. https://doi.org/10.1590/S1413-35552006000400009 32.Song $H J$, Son $H$, Seo HJ, Lee H, Choi SM, Lee S. Effect of selfadministered foot reflexology for symptom management in healthy persons: A systematic review and meta-analysis. Complem Therap Med 2015;23:79-89. https://doi.org/10.1016/j.ctim.2014.11.005

33. Chatchawan U, Eungpinichpong W, Plandee P, Yamauchi J. Effects of Thai Foot Massage on Balance Performance in Diabetic Patients with Peripheral Neuropathy: A Randomized Parallel-Controlled Trial. Med Sci Monit Basic Res 2015;21:68-75. https://doi.org/10.12659/MSMBR.894163

34.Rodrigues EV, Santos CR, Silva SF, Lissa M, Sturião MR, Stelmach CS. Massagem de reflexologia podal em idosas. Rev Conexão 2018;14:423-8. https://doi.org/10.5212/Rev.Conexao.v.14.i3.0014 